\title{
TRAPPING AND RELOCATING SEALS FROM SALMONID FISH FARMS IN TASMANIA, 1990-2000: WAS IT A SUCCESS?
}

\author{
by F. Hume, D. Pemberton, R. Gales, N. Brothers and M. Greenwood
}

(with three tables and five text-figures)

\begin{abstract}
Hume, F., Pemberton, D., Gales, R., Brothers, N. \& Greenwood, M., 2002 (31:xii): Trapping and relocating seals from salmonid fish farms in Tasmania, 1990-2000: was it a success? Papers and Proceedings of the Royal Society of Tasmania 136: 1-6.

https://doi.org/10.26749/rstpp.136.1 ISSN 0080-4703. Marine Conservation Unit, Nature Conservation Branch, Department of Primary Industries, Water and Environment, GPO Box 44, Hobart, Tasmania 7001, Australia (FH, RG*, NB, MG); Tasmanian Museum and Art Gallery, GPO Box 1164M, Hobart, Tasmania 7001, Australia (DP). * Author for correspondence.
\end{abstract}

In an effort to reduce the impact of seals on fish farms, the trapping and relocation of seals at Tasmanian salmonid farms began in 1990. To the end of May 2000, 353 identified individual seals had been trapped in 672 capture events. Most were non-breeding male Australian fur seals (Arctocephalus pusillus doriferus). The number of seals captured increased (from four in 1990 to a peak of 164 in 1998) with the size and extent of the farms, and an increase in salmon production from 55 tonnes in 1986/87 to almost 10000 tonnes in 1999/2000. Of 586 capture events $52 \%$ were of seals that had been captured more than once. When seals are recaptured following trapping and relocation, this occurs on average 25 days after capture. Capture-mark-recapture calculations show that many seals in the vicinity of fish farms are not 'trappable', suggesting that trapping is only effective for certain individuals. Some individuals are recaptured many times, reflecting the predisposition of some individuals to be captured ('trap-happy'). Interaction is seasonal, with most seals trapped during winter, between May and September. The assessment of trends in capture rates is problematic, due to the lack of capture effort information from the farms. A further confounding factor has been the change in management practice both between farms and over time, as the use of predator nets has become more widespread. Two seals trapped at fish farms and fitted with satellite transmitters before relocation have either not returned to the farm or returned to the vicinity of farms and not interacted with them, although on one occasion the individual was trapped. The effectiveness of the relocation program as a management tool to reduce seal interactions cannot be quantified from the relocation data per se, but relocation does not stop seals interacting with farms.

Key Words: seals, trapping, relocation, recapture, fish farms, Australian fur seal, New Zealand fur seal, salmon production, predator nets, Tasmania.

\section{INTRODUCTION}

The concentration of abundant potential food within fish farms is a major attraction to piscivorous predators and results in a significant management problem for fish farmers (Ross 1988, Pemberton et al. 1991). In the northern and southern hemisphere seals are the most prevalent predators at fish farms (Hawkins 1985, Ross 1988, Pemberton \& Shaughnessy 1993). The Australian fur seal (Arctocephalus pusillus doriferus) is the main predator interacting with salmonid fish farms in Tasmania (Pemberton et al. 1991).

Seal interactions result in the mortality of fish through direct consumption and stress to fish by attacks (Howell \& Munford 1991). Anecdotal evidence suggests that this stress prevents fish from feeding efficiently and can reduce growth rates (P. Warner \& S. Tideman, pers. comm.). Seal attacks may also result in damaged nets and escape of fish; net repair increases production costs. In the case of southern hemisphere salmonid fish farms, escaped fish become feral predators in marine systems (pers. obs.). In the northern hemisphere, where salmonids occur naturally, escaped salmon can interbreed with wild fish and thereby affect the genetic integrity of the natural populations (Fleming \& Gross 1993).

Since marine fish farms began operations in Tasmania in the early 1980s there has been a considerable increase in both the number and extent of fish farms. These increases have been met, not surprisingly, with an increase in the number of seal interactions. In Tasmania ten companies currently operate 26 fish farms growing Atlantic salmon
(Salmo salar) and Rainbow trout (S. gairdneri). Production from these farms has increased to an annual harvest exceeding 9000 tonnes of fish from an area of approximately 500 hectares (source: Department of Primary Industries, Water and Environment (DPIWE)).

\section{MANAGEMENT OF SEAL INTERACTIONS AT TASMANIAN FISH FARMS}

Since 1985, the Tasmanian Parks and Wildlife Service (TASPAWS) has been involved with seals at fish farms, due to its legal responsibility for the protection of seals in Tasmanian waters. TASPAWS has since provided advice and assistance in the trialling of various techniques to deter seals from attacking fish pens (Pemberton 1989, Pemberton \& Shaughnessy 1993).

Shooting (to scare or kill) was permitted in Tasmania (Section 35(1) Tasmanian National Parks and Wildlife Act 1970) as a method of seal control from 1987-95. Permits to shoot were issued under 'exceptional' circumstances, such as if a seal breached the protection systems, and on the provision that anti-predator nets be installed as quickly as possible. This policy attracted much criticism, but was seen at the time to be a temporary method to sustain farm production while protection barriers were improved.

As well as shooting, other deterrents, including pursuit with boats, seal crackers, lights, acoustic scarers and conditioned food aversion, have all been tried on fish farms in southeastern Tasmania (Pemberton \& Shaughnessy 
1993). None of these methods provided long-term effective mitigation of seal interactions with the farms. Predators such as seals are highly mobile, and localised persecution has only a short-term benefit because immigration is likely to replace those animals removed or killed (Howell \& Munford 1991). Additionally, of those seals that are scared from the lease, many return when the deterrent is relaxed (Pemberton \& Shaughnessy 1993).

The use of a predator net surrounding the stock net, forming a physical barrier between predators and the fish cage is the most effective method of predator control (Arnold 1992, Pemberton \& Shaughnessy 1993). The trapping and relocation of seals was introduced as a temporary method of seal control in 1990 to assist farmers while they trialled and improved the design of predator nets. After nine years of trapping and relocating and following consultation with the Parks and Wildlife Service and fish farmers in mid1998 it was agreed that this process be phased out by the end of 1998. Subsequent permits to continue to trap and relocate seals post-1998 were issued when 'exceptional circumstances' occurred, such as the need to drop predator nets because of reduced water flows or difficulty obtaining sufficient and optimal predator netting. To date (late 2001) permits are issued for trapping of seals after assessment and consultation between DPIWE officers and the fish farmer concerned.

This paper reports on the trapping and relocation of seals from fish farms conducted by the Nature Conservation Branch (NCB (DPIWE), formerly part of TASPAWS) from 1990-2000. The aims were to assess the efficacy of removal and relocation of seals as a primary mitigation method to protect fish farms from seal interactions. Aspects considered in this assessment included the type of seal trapped at farms, the likelihood of the return to the farm following relocation and the time elapsed between relocation and return.

\section{METHODS}

Trapping and relocation of seals began in 1990 at one farm and has since spread to all fish farms operating in southeastern Tasmania. The traps are c. $3 \mathrm{~m} \times 3 \mathrm{~m} \times 2 \mathrm{~m}$ in size and are made from reinforced steel mesh with a recommended mesh size of $5 \mathrm{~cm} \times 5 \mathrm{~cm}$. Attached floats keep the top $40 \mathrm{~cm}$ of the trap above the water and traps are either placed on the outer perimeter of the farm lease or adjacent to the pens being impacted by the seals. A sliding trap-door is triggered through a line which is baited with a dead salmon. Additional dead fish are sometimes attached around the cage to act as an added attractant. Traps are checked throughout the day and intermittently at night. Once a seal is captured, the designated relocation officer is notified and the seal is transferred into a transport cage and then towed to shore and lifted out of the water. Trapped seals are then transferred into the 'relocation trailer' and weighed on electronic scales before being taken to a veterinary clinic for assessment and final transport to the release site. Animal ethics regulations specify that seals are to be removed from the trap in the water within six hours and that the seal must be relocated within 48 hours of capture.

Since 1990, the method of marking seals has varied and has included paint marks, tagging, freeze-branding and the use of microchips (subdermal transponders). In the initial years of the program, all new seals were anaesthetised and then tagged or freeze-branded. A veterinarian examined all seals for general health, blood was taken for haematological, biochemical, toxicological and genetic studies; standard measurements (length and girth) were recorded. Since 1997, with the introduction of microchipping, which is a quick and efficient method of marking (and can be done by the person responsible for relocating), not all seals have received veterinary assessments. Seals (30 annually and those judged to be in poor health) which are bled for disease sampling are anaesthetised.

From 1990 to 1993, TASPAWS financed the trapping and relocation program. However, since 1994, the farms have been billed as the Service is no longer able to bear the costs. The initial cost was $\$ 400$ per seal and has since increased to $\$ 500$ per seal or $\$ 600$ if two seals are captured at the same farm at the one time.

The trapping and relocation data provided here were collected from 1990 until 30 May 2000, unless otherwise stated. Accordingly, the 1990 data and 2000 data do not constitute information for full years. Data relate to seals handled by TASPAWS personnel. Under some circumstances fish farmers illegally trapped and relocated seals themselves. We do not have access to those data.

The seals were relocated to several sites up to $600 \mathrm{~km}$ from the capture site (fig. 1). Some sites were used more frequently than others.

A capture-mark-recapture analysis (Caughley 1977) was carried out to calculate the total number of seals in the vicinity of a particular farm. One farm was chosen, based on the large sample marked (87 individuals at time 1 , 1997) and recaptured (45 individuals at time 2 in 1998). The Peterson Index (the estimate of population size) was the model used to estimate the total population at time 2 (Caughley 1977).

\section{RESULTS}

Six hundred and seventy-two seals have been captured at fish farms since 1990 (table 1). Where identified, all captures were of male Australian fur seals, except for one leopard seal (Hydrurga leptonyx) captured in 1996 and one New Zealand fur seal (Arctocephalus forsteri) in 1998. While most are undoubtably Australian fur seals, recent indications are that NewZealand fur seals could also be involved more commonly. Identification of the species is problematic (Goldsworthy et al. 1997) and the data presented here possibly include some incorrect identification. The number of seals captured steadily increased over time, reaching a peak in 1998. Substantially fewer seals were trapped in 1999 followed by an increase in 2000 (table 1). The extent of farm production has also increased substantially between 1990 and 2000 (fig. 2).

The weights of 257 captured seals ranged from $45 \mathrm{~kg}$ to $385 \mathrm{~kg}$ with a mean of $147 \mathrm{~kg}$ (s.d. $66 \mathrm{~kg}$ ) (fig. 3). Whilst body mass is an imprecise estimator of age, extensive field observations show that it is the larger (c. > $200 \mathrm{~kg}$ ) male fur seals which are more numerous at the breeding colonies. Using an arbitrary mass of $200 \mathrm{~kg}$ to indicate the difference between breeders and non-breeders, the trapped population was likely comprised mainly of non-breeding animals (78\% of weights were less than $200 \mathrm{~kg}$ ).

From the 672 captures, the individual identity was obtained in 586 cases, and 353 different individuals were recorded (table 1). Of the 586 identified captures, 303 $(52 \%)$ were of seals that had been trapped previously (table 


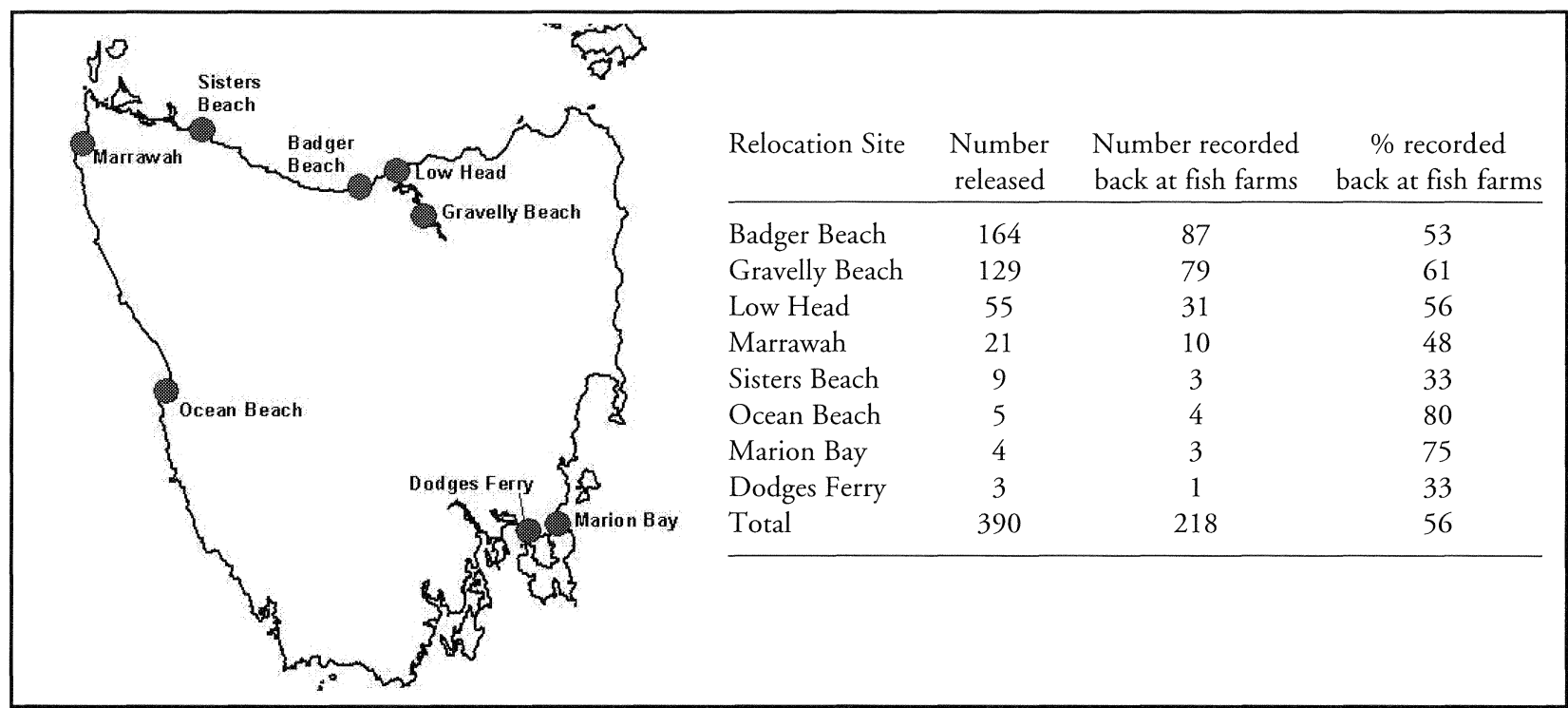

FIG. 1 - Map of Tasmania showing major relocation sites (where three or more releases have occurred), 1999-2000. Numbers of seals released and recaptured also shown.

TABLE 1

Numbers of trapped and relocated seals from fish farms in Tasmania, 1990-2000

\begin{tabular}{cccccc}
\hline Year & $\begin{array}{c}\text { All } \\
\text { captures }\end{array}$ & $\begin{array}{c}\text { Identified } \\
\text { captures }\end{array}$ & $\begin{array}{c}\text { Identified } \\
\text { individuals }\end{array}$ & $\begin{array}{c}\text { New* }^{*} \\
\text { individuals }\end{array}$ & $\begin{array}{c}\text { Captures } \\
\text { of new* } \\
\text { individuals }\end{array}$ \\
\hline $1990^{\dagger}$ & 4 & 2 & 1 & 1 & 1 \\
1991 & 11 & 10 & 5 & 5 & 10 \\
1992 & 21 & 14 & 9 & 9 & 14 \\
1993 & 36 & 34 & 22 & 22 & 34 \\
1994 & 45 & 39 & 22 & 16 & 29 \\
1995 & 23 & 16 & 7 & 3 & 3 \\
1996 & 37 & 25 & 14 & 10 & 15 \\
1997 & 164 & 125 & 68 & 62 & 110 \\
1998 & 164 & 156 & 80 & 56 & 85 \\
1999 & 59 & 59 & 53 & 36 & 37 \\
$2000^{\dagger}$ & 108 & 106 & 72 & 49 & 60 \\
Total & 672 & 586 & 353 & & \\
\hline
\end{tabular}

* Seals captured for the first time.

$\dagger$ Data from incomplete calendar years (see Methods).

2). While most seals $(66 \%)$ are captured only once in a year, some are captured twice $(17 \%)$ or three times $(10 \%)$. A small number of seals (7\%) are caught more frequently; the maximum recorded was two individuals caught more than ten times in one year. Most seals are captured and/or recaptured in only one year although a small number return in following years (fig. 4). Not all seals returned in consecutive years. One individual, for example, was captured three times in 1994, once in 1995 and then not recaptured until 1998, when he was captured once. The number of captures and recaptures has varied over time, partly because the capture effort by farmers has changed over time. For example, in 1999 extensive effort to protect fish pens via double netting reduced trapping effort and capture rates.

Captured seals were relocated to a range of sites on the

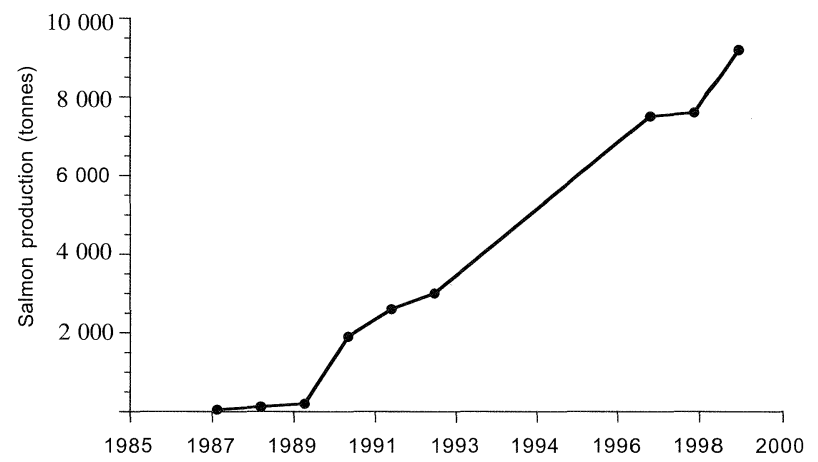

FIG. 2 - Atlantic salmon production (tonnes) at Tasmanian fish farms, 1987-1999 (information supplied by DPIWE).

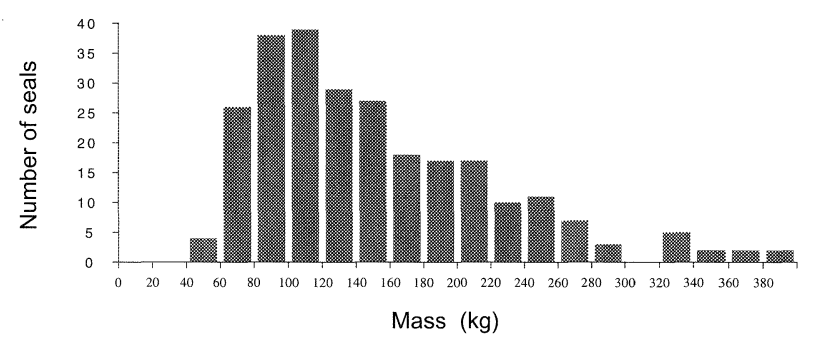

FIG. 3 - Body mass of male Australian fur seals trapped at fish farms in Tasmania, 1990-2000 $(n=253)$.

east, north and west coasts of Tasmania (fig. 1). Seals have returned from all major relocation sites. Most seals (74\%) were recaptured at the same farm as their initial capture (table 3).

While the time between recaptures is highly variable, on average the seals take 25.2 days (s.d. 22.1) before they are recaptured. In 1998, Badger Head was the major release site, the mean time till recapture was 25.2 days (s.d. $=21.4$ ) covering a minimum distance of $16 \mathrm{~km}$ each day. The fastest return from Badger Head was four days, a minimum distance travelled of $100 \mathrm{~km}$ per day. The data show that 
the presence of seals at fish farms is a seasonal occurrence, with a consistent peak in the months from May to September (fig. 5).

The mark-recapture analysis gave an estimate of 113 (s.d. = 10.7) individuals at time 2 (in 1998) for the farm where 45 individuals were captured (in 1987). This suggests that fewer than half of the animals foraging in the vicinity of the farm were captured.

\section{DISCUSSION}

\section{Species of Seal}

Three species of seal have been trapped at fish farms in Tasmania: Australian fur seals, one leopard seal and one New Zealand fur seal. From its inception in 1990, the trapping and relocation of seals from salmonid farms was used as a method of predator control, resulting in the capture of at least 586 individuals. Most of the trapped seals were identified as Australian fur seals with $73 \%$ of weighed animals classified as non-breeding animals. These data do not reflect the true proportion of fur seal species captured, because the two species commonly found in Tasmanian waters (Australian and New Zealand fur seals) are difficult to identify correctly (Goldsworthy et al. 1997), and some of the captured seals were identified by inexperienced personnel. Correct identification is important, as New Zealand fur seals may become more common around fish farms in Tasmania as their population is increasing in both South Australia and New Zealand (Shaughnessy 1999). The species is also known to use different methods of penetrating predator protection systems from Australian fur seals. New Zealand fur seals are known to climb over predator nets when attacking tuna pens in Port Lincoln (Pemberton 1997), whereas Australian fur seals are less adept at manoeuvring around pens and cages.

\section{The Number of Seals Captured}

The number of seals trapped increased (table 1) from four captures in 1990 to 164 captures in 1998 and 108 by late May 2000. Interpretation of this trend is difficult because of changes in trapping effort between farms and over time. For example, one farm was responsible for $30 \%$ of trapping events in 1998, 29\% in 1999 and 5\% in 2000. Similarly, for two other farms the relative proportions of trapped seals changed from $28 \%$ and $6 \%$ in 1998 , to $22 \%$ and $2 \%$ in 1999 , with no seals caught at either farm in 2000 . All three of these farms are managed by the same company, which restricted trapping from 1999 when new predator nets were introduced.

Another complicating factor is the concomitant increase in the size of the farms as shown by the tonnage produced (fig. 2). Seals prey on fish in the pens and wild fish which forage in the vicinity of the pens. Consequently, as the farm size increases, so their attraction to seals increases.

The seasonality of seal attacks by Australian fur seals at fish farms in southern Tasmania is probably a result of both the seasonal movements of the species and the location of food. Satellite tracking studies indicate that breeding females from colonies in eastern Bass Strait remain in Bass Strait throughout the year and females from Reid Rocks (western Bass Strait) frequent waters off the west coast of
Tasmania (unpublished data). Tagging studies and observations indicate that sub-adult and adult males disperse more widely than females, exploiting the southern Tasmanian continental shelf region (Warneke 1975, Brothers \& Pemberton 1990). These dispersing animals arrive in large numbers at the southern haul-outs in late summer (Brothers \& Pemberton 1990). They feed and moult, and by May the numbers interacting with the inshore fish farms increase (fig. 5). This influx to inshore waters could be because of changing foraging conditions offshore. The number interacting with fish farms steadily increases until October. At the start of the breeding season, towards mid-October, there is an influx of seals to the breeding colonies and this coincides with a rapid decline in the number of seals interacting at fish farms (fig. 5).

\section{Recaptures}

Fifty-two percent of the total identified captures, since 1990, are recaptures (table 2). In 1997, 48 new individuals accounted for $76 \%$ of the recaptures; the remaining 15 individuals $(24 \%)$ had been captured in previous seasons. In 1998, however, 29 new individuals accounted for $29 \%$ of the recaptures and 71 individuals from previous seasons made up $71 \%$ of the recaptures. This shift may be explained by an increased trapping effort, instigated in 1997, which would increase the probability of capture for those animals new to the food source in that year. This recapture pattern probably reflects the ability of the seals to exploit a new resource.

Most seals are caught only once, although $17 \%$ of seals have been caught twice and $10 \%$ caught three times. The capture frequency of individuals may increase over time with continued trapping and industry expansion. As more seals discover this predictable food source, there is an increased chance of recapturing individuals which acquire a taste for salmonids in the pens and traps, and the wild fish attracted to the pens. Most seals that are trapped at the farms are trapped in only one year (fig. 4); 40\% are caught in following years, generally in consecutive years, but some seals are not recaptured for a year or more. Many are not retrapped and, if this is used as a measure of success, trapping and relocation does reduce the number of seals close to a farm for a period of time.

Some seals are trapped repeatedly in the same year or repeatedly in following years. An example of this is one individual captured nine times in 1997, 16 times in 1998 and 14 times in 2000 (not trapped in 1999). This individual and the other multiple-captured seals reflect a trapping behaviour shown by many mammals and termed 'traphappy' (Caughley 1977). In most mammal studies based on trapping individuals there is also a portion of the population that is trapped less frequently and termed 'trapshy'. Another portion of the population is 'untrappable'. In the case of the fish farms, the 'trap-shy' and 'untrappable' animals are not controlled by the trapping management practice. 'Trap-happy' individuals are sometimes perceived as rogues and implicated in the damage to pens and fish. This is conjecture as a trapping event shows only that the animal is trappable and in the vicinity of the fish pens.

The total number of animals interacting with the fish farm includes both the trapped sample and untrapped sample. Sufficient data existed to calculate the total population for one farm; this showed that 45 seals were 
TABLE 2

Numbers of recaptured seals per year from fish farms in Tasmania, 1990-2000

\begin{tabular}{ccccccc}
\hline Year & $\begin{array}{c}\text { All } \\
\text { recaptures } \\
(n)\end{array}$ & $\begin{array}{c}\text { Recaptures as } \% \\
\text { of identified } \\
\text { captures }\end{array}$ & $\begin{array}{c}\text { New } \\
\text { recaptures } \\
(n)\end{array}$ & $\begin{array}{c}\text { New } \\
\text { recaptures } \\
(\%)\end{array}$ & $\begin{array}{c}\text { Recaptures from } \\
\text { previous seasons } \\
(n)\end{array}$ & $\begin{array}{c}\text { Previous seasons } \\
\text { recaptures } \\
(\%)\end{array}$ \\
\hline 1990 & 0 & 0 & 0 & 0 & 0 & 0 \\
1991 & 5 & 50 & 5 & 100 & 0 & 0 \\
1992 & 5 & 36 & 5 & 100 & 0 & 0 \\
1993 & 12 & 35 & 12 & 100 & 0 & 43 \\
1994 & 23 & 59 & 13 & 57 & 10 & 71 \\
1995 & 13 & 81 & 0 & 0 & 13 & 24 \\
1996 & 14 & 56 & 5 & 36 & 10 & 71 \\
1997 & 63 & 50 & 48 & 76 & 15 & 86 \\
1998 & 100 & 61 & 29 & 29 & 71 & \\
1999 & 23 & 39 & 1 & 4 & 22 & \\
2000 & 57 & 53 & 11 & 19 & 46 & \\
Total & 303 & 52 & 129 & & & \\
\hline
\end{tabular}

TABLE 3

The number and location of recaptures of seals at fish farms in Tasmania, 1990-98

\begin{tabular}{|c|c|c|c|c|c|c|c|c|c|c|}
\hline \multirow[b]{2}{*}{$\begin{array}{l}\text { Initial capture } \\
\text { farm* }\end{array}$} & \multicolumn{10}{|c|}{ Recapture farm ${ }^{\dagger}$} \\
\hline & K & $\mathrm{L}$ & $\mathrm{H}$ & $\mathrm{J}$ & I & G & E & C & B & A \\
\hline K (211) & $84(84 \%)$ & & 1 & 2 & 1 & 1 & 1 & 8 & 1 & 1 \\
\hline L $\quad(1)$ & 1 & & & & & & & & & \\
\hline $\mathrm{H} \quad(65)$ & & & $16(76 \%)$ & & & 2 & & 3 & & \\
\hline J (21) & & & & 2 & 1 & & & 1 & & \\
\hline I (6) & & & & & & & & & & \\
\hline G (62) & 1 & & 5 & & & $35(85 \%)$ & & & & \\
\hline E (2) & & & & & & & & & & \\
\hline C $(90)$ & 4 & & 6 & 2 & & 1 & & $30(65 \%)$ & 2 & 1 \\
\hline B (11) & 2 & & & & & 1 & & 10 & & \\
\hline A & & & & & & & & & & 2 \\
\hline
\end{tabular}

* Total captures in brackets.

${ }^{\dagger}$ Codes used to protect farm identity.

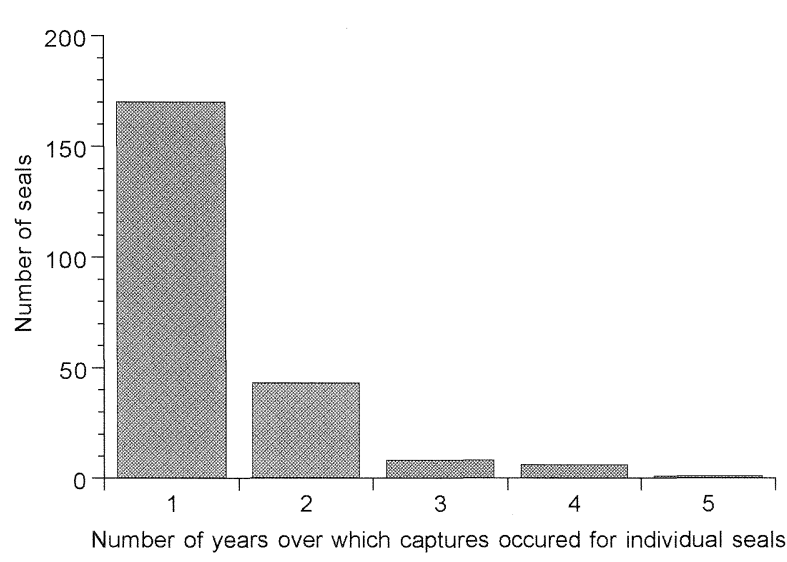

FIG. 4 - Number of seals trapped in one year, or in years subsequent to initial capture, at fish farms in Tasmania, $1990-2000$

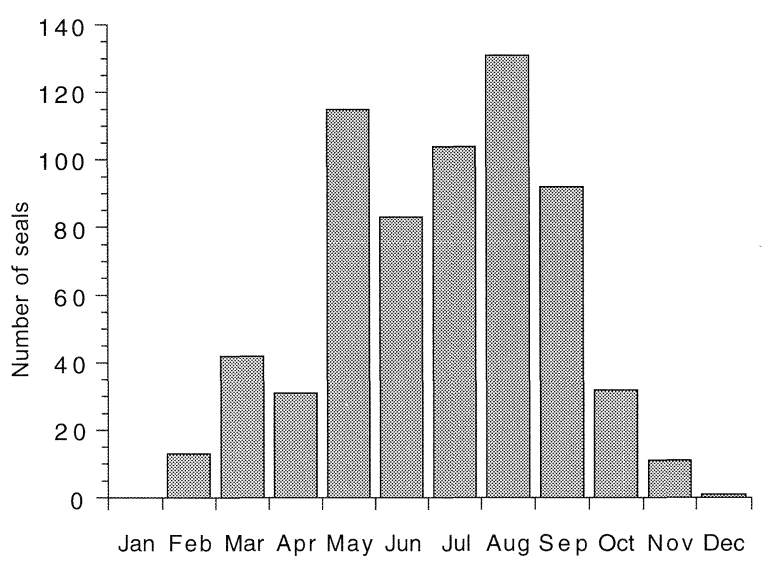

FIG. 5-Number of seals trapped each month at fish farms in Tasmania, 1990-2000. 
caught but the population was estimated to be 113 . There are many assumptions associated with this type of calculation, for example, the need for marked animals to be selected at random, the recapture sample being random with regard to whether animals are marked or unmarked, and the need for the population to be closed (Caughley 1977). In this study, as in many other wild animal trapping programs, these assumptions may have been violated to some extent. Nonetheless, it is apparent that many seals are not caught and that the size of the population interacting with the fish farm is considerably greater than the number caught, hence a limitation of trapping as a management option.

\section{Behaviour after Release}

Many relocation sites have been used since 1990, and seals have returned from all major relocation sites (fig. 1). It is evident that, regardless of where seals are relocated, they are able to return, and they can return in a similar time from any of the relocation sites. The time between recaptures is, on average, 25 days which means that the farm has a significant period without the presence of that particular seal, a factor some farmers consider sufficient to justify relocation as a management tool.

Seals that are recaptured mostly return to the site of original capture, showing fidelity to one particular farm for up to five years (table 3). This behaviour is also shown by Australian fur seals which have been satellite tracked from the breeding colonies in Bass Strait. Individuals from Tenth Island routinely frequented particular areas (unpublished data). It appears, therefore, that individual seals learn about predictable food sources and utilise them both within and between years.

\section{CONCLUSION}

This study demonstrates that seal relocation is not effective as a primary protection method to protect fish farms from seal interactions. Effective predator nets should be used whenever seal interactions are a problem. One of the limitations of the use of predator nets is the cost of net management, particularly in summers when warm water results in increase growth of fouling organisms on the net and resultant loss of water flow, which affects fish health. The strong seasonal nature of seal interactions suggests that in the warmer months only, when there are fewer seals and more fouling of nets, relocation could be considered as a part of a management strategy when 'exceptional circumstances' of individual seal interactions are encountered. In winter and spring, when seal interactions increase, appropriate, effective predator nets are essential at all times. The management of nets at this time is easier, because fouling is less of an issue. This rotation of predator control methods, as well as further investigation into more effective mitigation techniques, will help to reduce the numbers of seals transported and assist in more efficient and cost-effective farm management.

\section{REFERENCES}

ARNold, H., 1992: Experimental predator control measures on marine salmon farms in Shetland. Submission to the Planning and Coordinating Committee of the Marine Mammal Action Plan, United Nations Environment Program.

Brothers, N.P. \& Pemberton, D., 1990: Status of the Australian and New Zealand fur seals at Maatsuyker Island, Southwestern Tasmania. Australian Wildlife Research 17: 563-569.

Caughley, G., 1977: Analysis of Vertebrate Populations. John Wiley \& Sons, Chichester: 232.

Fleming, I.A. \& Gross, M.R., 1993: Breeding success of hatchery and wild coho salmon (Oncorhynchus kisutch) in competition. Ecology 33: 893-905.

Gales, R.P., Kirkwood, R., Pemberton, D. \& Renouf, D., 1993: Size and shape of the Australian fur seal, Arctocephalus pusillus doriferus. Marine Mammal Science 9(1): 99-103.

Goldsworthy, S.D., Pemberton, D. \& Warneke, R., 1997: The field identification of Australian and New Zealand fur seals Arctocephalus spp., based on external characters. In Hindell, M. \& Kemper, C. (Eds): Marine Mammal Research in the Southern Hemisphere. Surrey Beatty and Sons, Chipping Norton, Sydney: 63-71.

HAWKINS, A. D., 1985: Seal predation at salmon farms. Working Paper No. 8/85. Department of Agriculture and Fisheries for Scotland Marine Laboratory.

Howell, D.L. \& Munford, J.G., 1991: Predator control on finfish farms. In DePauw, N. \& Joyce, J. (Eds): Aquaculture and the Environment. European Aquaculture Society, Special Publication 16. Gent, Belgium.

Pemberton, D., 1989: The interaction between seals and fish farms in Tasmania. Unpublished report. Department of Lands, Parks and Wildlife, Tasmania.

Pemberton, D., 1997: Port Lincoln tuna farms, dolphins, seals, sharks and seabirds. Report to South Australian Research and Development Institute and Tuna Boat Owners Association, South Australia.

Pemberton, D. \& Shaughnessy, P.D., 1993: Interaction between seals and marine fish farms in Tasmania, and management of the problem. Aquatic Conservation: Marine and Freshwater Ecosystems 3: 149-158.

Pemberton, D., Brothers, N. \& Copson, G., 1991: Predators on marine farms in Tasmania. Papers and Proceedings of the Royal Society of Tasmania 125: 33-35.

Ross, A., 1988: Controlling nature's predators on fish farms. Unpublished report for the Marine Conservation Society, Ross-on-Wye, UK.

Shaughnessy, P.D., 1999: The Action Plan for Australian Seals. Environment Australia, Canberra: 116 pp.

WARNECKE, R.M., 1975: Dispersal and mortality of juvenile fur seals Arctocephalus pusillus doriferus in Bass Strait, southeastern Australia. Rapports et Proces-Verbaux des Reunions Conseil International pour l'Exploration de la Mer 169: 296-302.

Woods, R., Cousins, D.V., Kirkwood, R. \& Obendorf, D.L., 1995: Tuberculosis in a wild Australian fur seal (Arctocephalus pusillus doriferus) from Tasmania. Journal of Wildlife Diseases 31(1): 83-86.

(accepted 17 June 2002) 